\title{
Nature Theme Pictured Book Used in Teaching English for Elementary Students
}

\author{
Andi Febriana Tamrin ${ }^{1}$ and Sulmi Magfirah ${ }^{2}$ \\ English Literature Department, Fajar University ${ }^{1,2}$ \\ Email: andifebriana9o@gmail.com ${ }^{1}$
}

\begin{abstract}
This study aims to find the use of picture in helping students to learn basic English and to increase their awareness of the natural environment. In the long run this research aims to provide a basic method for learning English in elementary schools. The title of the picture books used in this research is "Our Big Home: An Earth Poem". A qualitative descriptive is applied in this study that aims to create a conceptual model of learning based on storybook. The population used in this study was elementary school located in Malino sub-district, Makassar city. In selecting the technique sample used is a multistage sampling technique. This research applied the data analysis technique of this research is processing data based on the flow method. The result showed that most of the children showed high interest in learning English by using this method and it was also catch the student's interest to care more about their natural environment by comparing the illustration in the book.
\end{abstract}

Keywords: English learning model, picture book, elementary school.

\section{https://ojs.unm.ac.id/eralingua}

\section{INTRODUCTION}

The rapid development of technology at this time significantly affects the environmental damage that occurs on planet Earth. Findings created by humans have goals that tend to make their lives easier. However, the ingredients they use for this invention come from nature such as trees, rocks, and water. As a result of using this raw material, it causes pollution which endangers the Earth's atmosphere. This means that the more advanced human innovation, the more dangerous our environment. As a creature that has more knowledge than other beings, humans should be able to protect the surrounding environment. Awareness of the importance of preserving nature for the survival of humanity should begin as early as possible. One of the best ways is through education. Why is education? This is because to make students to experience changes that cover three aspects; cognitive, affective and psychomotor, education is needed as an effort to realize an awareness and planned to achieve a goal. So from that education is the right to increase human consciousness about the natural surroundings. Education for children as well as the primary target is a more appropriate way to start this.

English subjects in elementary school are one of the many lessons taught in school. As a world language, English can make a significant contribution in life, both in formal and informal situations. Some other developing countries have used 
English for their daily needs. Therefore, this lesson is very appropriate as one of the media to increase children's awareness of their environment. Learning English for environment-based elementary school children is currently not fully considered necessary by the government. Even if it is explored more deeply, the learning method will be beneficial in increasing awareness of the importance of protecting the environment as early as possible. This learning method will also improve children's language skills which will be very useful for their lives in the future. Unfortunately, this seems to be constrained by the many assumptions in the community who think that mastering English will make them forget their local culture and language. If this continues to be an essential reference for English for children, their awareness of the environment will diminish. Of course, automatically soft skills that should help them in the future will not be realized.

There are several appropriate ways to bring students closer to nature through learning English, one of which is by holding a field trip or holding classes outside the classroom (school) and through learning media in the classroom and school environment. According to studies from Children and Nature Network, an organization that has a focus on reconnecting children and nature, in the future in the future they will be able to preserve the environment where they grow up. This indicates that as early as possible children are introduced to guard their nature, so they will be able to protect it as soon as possible too. One other way to implement this learning is through teaching media in the form of picture books. According to Lynch-Brown and Tomlinson, picture books that have been freely illustrated are significant to give readers an understanding of the story. Whereas according to Lankford, the meaning of picture books can be built through the relationship between text and illustrations that provide a core role in shaping the point of view in a narrative story.

To increase awareness of the environment and the surrounding environment, picture books are one of the most appropriate and powerful learning tools to use. Authors and illustrators express their ideas on this topic in their work, namely picture books. One of the recommended picture books for the application of this learning method is a picture book that tells about the local and regional environment of students. This is because they will feel familiar situations and conditions that will make them feel comfortable and connected to their surroundings. They will also find it easier to understand the story. At present, there are many picture books with environmental themes that are scattered in our society. Adults today also have more interest in environmental topics. The use of pictorial media in the form of children's stories in learning English using natural or environmental approaches has not been fully applied in Indonesia, especially in South Sulawesi Province, Makassar. There are even some elementary schools that have eliminated eyes English lessons. This is very unfortunate especially in areas that have many natural attractions that facilitate this method. The method and approach to nature in learning English in its application will not provide many challenges for children. The primary purpose of this learning is to bring children closer and increase awareness of the importance of preserving nature as their place of residence now and in the future. 


\section{LITERATURE REVIEW}

\section{Picture Books}

Everything that is manifested visually into a two-dimensional form as a result of feelings and thoughts is a simple understanding of images. In the implementation of the picture, the education process can be used so that it is possible to occur the teaching and learning process. In the process of selecting images must be done carefully and precisely. This is because the target of learning is school students, so the model used as a learning tool must be exciting and can stimulate students to give a good response in education. Picture storybooks are books in which there are pictures, words, where the words and words do not stand alone but are interdependent to become a unified story, Mitchell in Faizah (2009: 252). Whereas according to Ardianto (2007) pictorial stories are an art form that uses immovable images arranged in such a way as to form a storyline. Picture stories are storybooks that have pictures, but their shape in a story or narrative is not in the form of information. Thus illustrated storybooks are by the characteristics of storybooks, having story elements in them (characters, plots, characters, grooves). This book can be divided into two types, (1) illustrated storybooks with words, (2) picture storybooks without words. Both of these books are commonly used for preschool students or students in elementary school in the early grades.

Picture storybooks are a combination of text and illustrations. Fleming and Billman (2012: 4) state that "the text in illustrated storybooks must provide a balanced perspective and do not emphasize the issue in the story, and the content must also be accurate for a non-fiction book." According to Lankford, the meaning of a storybook is built through the relationship between the text and its illustrations. Text and pictures have a role important in shaping perspectives or points of view in a story or narrative (2010). Illustrations have an active role in picture books. Words are only able to describe space, but illumination can "show the true description." A well-illustrated storybook has one picture on each page. Illustrations are also able to give mood and setting in a story. Another function of the illustration is that it can help define and construct characters that cannot be fully explained by text or words. Illustration forms a character based on the situation and emotions described in the story. Illustrations can complement characterizations in the text by showing the actions and reactions of each other's characters by giving an additional description of the character.

Picture stories will have a positive impact not only on children but also for adults. This is because in general, the stories contained in illustrated storybooks usually teach the value of life. For example, obeying parents, brush your teeth before going to bed and of course the relationship between humans and their environment or nature. This can be the basis that illustrated storybooks can be an effective means for children. As stated earlier, illustrations in illustrated storybooks have an essential role for the reader. Illustrations in illustrated storybooks also have the purpose of providing a visual imagination to a children's reader. This is so that children can absorb and understand the stories contained in the book quickly. An illustration of the illustrations contained in the book will help children to create 
images by the illustration. So from that, it can be said that picture books have many benefits for early childhood.

\section{Ecocriticism}

As one of the academic disciplines that began to be promoted in the 1990s, although initially began to develop in the 1970s. This field of science deals with literature and ecology (environment) physically. Because it is still considered new, experts are still involved in defining the scope and purpose of the subject. In addition to publishing literary works, this study also reviews the criticisms of environmental literature and conducts various researches on objects related to ecocritics. Ecocriticism is a study that connects literary works with the physical environment, population growth, loss of wild and wild forests, rapid extinction of species, and increased contamination of air, water, and soil on earth (Love, 2003: 1). Ecocriticism gives attention to the reciprocal relationship between literary work and the environment, including relations with social and physical reality, which is usually a concern in ecology (Love, 2003: 1). From the ecocritical boundaries, it can be concluded that the study of literature (in this case the novel) using Ecocriticism will explain how nature, the environment, with its various problems become an inseparable part of literary work. In this case, nature and the environment, not only understood as the setting of the place and atmosphere, but also an aspect that helped build the aesthetics of a literary work.

Nature and the environment are areas of study in literary science, especially by using an ecocritical perspective. Philips in Sayuti (2014: 5) there are several criteria that deserve to be called green literature in a paper either prose or poetry. First of all the language used contains a lot of diction, the contents of the work are based on love for the earth, sadness on the destroyed earth, expressions of anxiety in uncovering the destruction of the earth, against injustice for abuse of nature and its contents (trees, mines, water, air , and its inhabitants), the idea being implemented is the liberation of the earth from destruction. Green Literature has a vision and mission of awareness and enlightenment that is expected to change the destructive lifestyle so that the keeper takes care of the earth (go green).

The work that uses Ecocriticism as his theory looks at the relationship between the author, the text, the environment and the natural surroundings. Ecocriticism in its use questions the relationship between humans and their environment, the role of nature in a story, how to save the environment after being destroyed by humans, the balance between the environment and the life cycle that is destroyed by humans and so on. According to Tosic, literary criticism is interested in the relationship between humans and the physical condition of their environment. In this century, humans were aware of the natural environment around them actually had been destroyed in succession. Raising awareness about the environment and the surrounding environment is the main task that is quite heavy for ecocritics. This will be more effective if we instill an understanding of nature starting at an early age. Ecocritics have a short history when associated with the world of child literature (Lankford, 2010: 16). Lensik-Oberstein in Lankford also explains this history in his essay: "The bond between children and the environment arises generally because John Locke believes in the existence of "true nature" in children. 
Locke implies that nature is both defined and real while it also reflects the pure and simple nature of a child. Pairing children and nature allows adults and parents and also writers for children to create a connection between the presence of nature and the understanding of children themselves (Lankford, 2010: 16).

Using illustrated storybooks that have ecocritical themes to increase awareness of nature has many advantages. One of them is a driving factor for making children return to nature. This is because nowadays children tend to be kept away from life and their environment. The only experience that children often learn about nature is through television. Chipeniuk in White (2006: 3), documentary films on tv and saving nature by raising funds make children think that nature is exotic but far from their reach. One way to get their attention to increase awareness of nature, adults must be able to provide information and encourage them to seek experience in the surrounding environment. This is because to make them understand that the natural world is straightforward to live through and of course everyone can have experience in nature.

Kreisberg in his book "Teaching Children about the Environment with Pictures Books" suggests that the instructor or teacher must provide children with several picture books on topics such as plants, wildlife, insects, habitats, and so on. This will give some information needed before they are ready to jump into the field. The use of illustrated storybooks on environmental themes in learning English to increase awareness of the surrounding environment can use several books specifically with the idea of children's literature. The illustrated storybook will undoubtedly be able to attract the attention of children in learning situations. Pure material through the introduction of simple vocabulary in pronunciation is mainly a mandatory requirement for picture books.

\section{English Learning for Children}

In the current era of globalization learning English should not be underestimated. Teaching English for Young Learners (TEYL) or better known in Indonesian as learning English for children - children are a branch of science that is still developing and relatively new. This lesson was born because of the many results of studies that state that learning English will be more effective if it starts from an early age. This is because in the theory of linguistics children at an old age tend to absorb their knowledge more quickly. This is supported by Krashen's theory (1985) which states that students not only learn about language (learning) but can gain knowledge about being able to speak like an acquisition. Other studies have also proven this, Fillmore (1979) states that children who learn languages at an early age have different learning strategies compared to students who are older.

In countries where the primary language is not English, TEYL teaching can be said to be global. One state that follows this trend is Japan. In this cherry country, in the field of teaching English, the teaching staff recruited come from countries that do use English as their main language. This contrasts with the situation in Indonesia. Teaching English for children to date in teaching is still the same as in high school. Learning like this is dominated by the use of textbooks coupled with monotonous teacher explanations. In the TEYL theory, the use of textbooks as a learning medium as the only source of learning in the classroom is very ineffective. If you 
only use textbooks as a learning resource, this certainly will not provide an opportunity for students to learn English that is used in real life. Communicative English Learning should have a paradigm shift in its teaching. Change must begin with the use of textbooks, direct education from teachers and teaching methods are no longer placed as the main factors in assessing the success of English language learning. Brown (2007: 60), mentions the principle of language learning as follows: successful mastery of the language will be a large extent to a Learner's own personal "investment" of time, effort, and attention to the form of an individualized battery for comprehending and producing the language.

So, language learning to achieve success is primarily determined by its learning strategy. This language learning strategy includes the domain of understanding and producing language. Richard and Schmidt (2010) generally divide learning strategies can be interpreted as "how attempts to work out the meanings and uses of words, grammatical rules, and other aspects of language they are learning". Learning English in Indonesian elementary schools has been applied for more than ten years. However, as stated earlier the English learning curriculum applied was still very much flawed. As subjects placed in local content in the curriculum, the purpose is not by the development of children for ages 6-12 (primary school age). The purpose of teaching foreign languages in elementary schools is to introduce to students that besides the mother tongue (Indonesian) that they have known so far there are other languages (foreign languages) that deserve to be studied. Therefore, English should be introduced through activities that are more suitable for the world of children. For example, learning vocabulary through illustrated storybooks and learning through the surrounding environment or learning English through field trip methods or outside the classroom The scope of this study is not only for elementary school students but can be applied to children outside of teaching and learning activities such as home learning that can be done by their parents. The hope is that by using illustrated storybooks, children with environmental themes in learning English can also be applied at home by parents.

\section{RESEARCH METHOD}

Ratna (2009: 34) provides an understanding of methods, methods are considered as strategic ways that are used to understand reality, systematic steps to solve a series of subsequent causes and effects. The technique serves to simplify the problem, making it easier to get a solution and understanding. This study uses a type of qualitative descriptive analysis research. Qualitative methods pay attention to original data, data about the context of its existence. Qualitative methods are also considered to be multimode because research, in turn, causes a large number of relevant social symptoms (Ratna, 2009: 34). Whereas regarding etymology the description and analysis mean outlining the core of the research subject.

\section{RESULT AND DISCUSSION}

\section{First visit}

The first visit to Pattapang Elementary School was an observation activity to collect the desired sample data. The results obtained are, the first sample (class 1) 
has 18 students and the second sample (class 2) has 11 students. After obtaining sample data, the researchers then asked brief questions about English and nature. The questions raised by researchers are 1) do you know what English is? 2) Do you know what nature is? 3) Have you ever seen or read a picture book? Of the three questions asked by the researchers, 21 students answered 'no' and 8 students answered 'yes'. The 'no' answer issued by the children was triggered by the absence of English language subjects in their school and the lack of debriefing about nature, and the media they used in the form of printed books that had less or fewer pictures / illustrations. This was known after researchers conducted interviews with teachers at Pattapang Elementary School, Malino.

\section{Second Visit}

After processing sample data from the first visit, the researcher made a prestudy questionnaire. Pre-study questionnaire. On the second visit, researchers taught students in grades 1 and 2 of Pattapang Elementary School a little about English and nature using picture books. Some students seemed enthusiastic in learning English and listening to discussions about nature and some students did not look enthusiastic or bored. After giving a brief lesson, the researcher divided the Pre-study Questionnaire. From the results of the pre-study questionnaire, it was found that students in grade 1 and 2 of SDN Pattapang still answered "no". Of the 29 questionnaires filled out, 18 of them filled out the answer 'no' more than the answer 'yes'.

\section{Third Visit}

On the third visit, researchers invited students in grade 1 and 2 to study outside the classroom (outdoor). This is done to bring them closer to nature. The researcher again taught them English using a natural-themed picture book media. From outdoor learning, the atmosphere that supports the method of learning English is carried out by researchers. Researchers can compare what happened in the picture book with what happened around their school environment. In a picture book used by researchers, students can see that the nature in the book is very different from reality. Some students can judge that they want nature as in the book, blue sea, cool wind, fertile soil and pollution free air and of course a clean environment where they can play without worrying about getting sick. It can be concluded that the results of the third visit have formed a little awareness of some students in grade 1 and 2 of Pattapang Elementary School, Malino about the nature around them.

\section{Fourth Visit}

During this visit, researchers used the student learning center method. Researchers make students read poems in picture books in front of their friends. Some students can read well, and some also vice versa. However, what is judged is not how they read, but their enthusiasm which can be said to have increased since outdoor learning on previous visits. Students scramble each other's turn to read poems in picture books. The results of the fourth visit indicated an indication of increased interest in natural-based English learning. Of the $80 \%$ of all samples who answered 'no' at the first visit and questionnaire on the second visit, $40 \%$ of them 
had shown interest and interest in learning English using natural-themed picture books.

\section{Fifth Visit}

On this fifth visit, researchers invited students for more outdoor learning. The method used this time is learning English while cleaning the school environment. Students are invited to clean up the garbage around their school, of course using simple English that has been taught before. At the end of the teaching, the researcher assigns the task to find some English vocabulary about the nature around their house. The results of this fifth visit show that since the implementation of this study, students who are enthusiastic about nature and learning English have increased, although there are still some students who have not been moved to care about their surroundings and are interested in learning English.

\section{Sixth Visit}

On this sixth visit, the researcher conducted a test on what was taught on previous visits. This test aims to find out how far students understand about what has been taught. Test performed there are two stages, namely the oral stage and the writing stage. At the oral stage, the researcher asks or reviews verbally about the contents of the picture book used in this nature-based learning method and the vocabulary they have heard and learned during learning. At the writing stage, the researchers made 10 questions about nature and of course they had to answer in English. The written questions were:

a. English from Earth is ......... (Earth)

b. Nature is very important to be guarded for the good of all of us, we may not dispose of (garbage) in random places

c. In the picture book, there are 10 parts that explain nature, 3 of which are (water) .. (soil), and (wind)

d. In the picture book in the first part, we can see children and animals playing ...... (water) on the beach

e. ....... (sun) always gives us warmth and gives plants life.

f. Around our school, there are many ...... (plant)

g. Near my house there are ......... (tree) mangoes, apples and papaya.

h. At Malino, ....... (wind) it is very cold.

i. We all play kites using help ...... .. (wind)

j. Animals, plants, trees, and we are all part of ........ (nature)

The results of the two tests conducted indicate changes in student attitudes and behavior students towards the environment. Those who initially did not know about nature, now care more about the nature around them. Their understanding that it is easy to absorb natural-themed English learning, as well as the environmental influences around their schools that support natural-themed learning methods indicates this.

\section{Seventh Visit}

During this visit, researchers require students to give their opinions about nature in in a picture book. Learning is done outside the classroom (outdoor). The purpose of this visit was to get the opinions of children about the nature around them, whether the nature around them or their schools still gave them positive 
energy or even made them sick. As we know, the destruction of nature makes the air polluted by pollution such as dust, vehicle fumes and exhaust fumes from factories, the land becomes dry due to global warming, and water (rivers, lakes, and others) that become polluted due to waste disposal and waste. The results of this visit were that students consisting of ages 6-9 years had different opinions. They argue that the air here is usually 'batukki', 'water is clear and clear', 'lots of trees are cut down', and 'lazy ki plays kites because of heat' using a Makassar accent. From their diverse opinions, students unconsciously use ecocriticism towards the environment or nature around them.

\section{The Eighth Visit}

In the Eighth or the last visit is a day to determine the final outcome of the entire series of visits. The researcher reviewed all learning on previous visits. Students on the first visit who knew almost nothing about nature or English, now had an understanding of these two things. The indicator that shows this is that the students are enthusiastic in answering the questions issued by the researchers as well as the condition of their class which was originally a lot of scattered garbage (paper waste and plastic food wrapping). The result of this visit was that students' awareness of the environment was formed and increased since learning English using natural-themed picture books. The trigger for increasing student awareness is an illustration in a picture book that attracts students to read and understand it, as well as natural-themed English poems in picture books that make students gain knowledge of English vocabulary.

\section{Final Results}

From a series of visits that have been conducted, a total of 8 visits, the researchers concluded that the method of learning English using picture books to increase awareness of the environment is an efficient method. The picture book that is used as a learning medium attracts students to read it because the illustrations are intended for children and the poems are easy reading. During the learning process, students can capture the material given in a straightforward manner. Straightforwardly in the sense, the researcher provided material that was in accordance with the picture book content and its relation to nature, of course using English mixed with Indonesian with a little Makassar accent. The results obtained were an increase in students' awareness of the nature around them which was seen in the preview on the eighth visit. The researcher saw several students who after eating snacks threw the plastic wrap of food in the same place. They also maintain class cleanliness and the environment around the school. The researcher also found students' interest in learning English and children's literature. Their interests range from reading (reading), children's literature (children's literature), and picture books.

\section{CONCLUSION}

Based on the results of research on the method of learning English using a picture book to increase awareness of the environment it is known that children who are given this method can understand and absorb the material provided straightforwardly. This was triggered by their interest in the pictures or illustrations 
contained in the picture book. Children also learn English from poems in picture books. Natural-themed poetry also increases children's awareness of the surrounding environment. Children will unconsciously compare what happened in the book and the environment around them. They can see the clean nature in the book then criticize the environment around them which is not as impressive as in the book.

\section{REFERENCES}

Ardianto, Tommy. (2007). Perencanaan Buku Cerita Bergambar Sejarah Goa Selonangleng Kediri. Surabaya: Universitas Kristen Petra.

Brown, D.H. (2007). Teaching by Principles: An Interactive Approach to Language Pedagogy. N.Y: Longman.

Faizah, Umi. (2009). Keefektifan Cerita Bergambar Anak untuk Pendidikan Nilai dan Keterampilan Berbahasa dalam Pembelajaran Bahasa Indonesia. Tesis. Yogyakarta: Program Pasca Sarjana, Universitas Negeri Yogyakarta.

Fillmore, C.J., Kempler, D., and Wang, W.S-Y. (Eds.). (1979). Individual Differences in Language Ability and Language Behaviour. New York: Academic Press.

Fleming, Louise Conn, and Linda Webb Billman. (2012). Using Children's Literature to Enhance Environmental Literacy. Environmental Education Council of Ohio.

Krashen, S. (1985). The Input Hypothesis: Issues and Implications. New York: Longman.

Kriesberg, Daniel A. (1999). A Sense of Place: Teaching Children About the Environment with Picture Books. Colodaro: Teacher Ideas Press.

Lankford, Megan. (2010). Nature and Grief: An Ecocritical Analysis of Grief in Children's Literature. MA. Thesis. University of British Colombia.

Love, A. Glen. (2003). Practical Ecocritism: Literature, Biology, and the Environment. University of Virginia Press.

Lynch - Brown, Carol and Carl M. Tomlinson. (1993). Essential of Children's Literature. Boston:Ally and Bacon.

Nurgiyantoro, Burhan. (2005). Sastra Anak Pengantar Pemahaman Dunia Anak. Yogyakarta: Gadjah Mada University Press.

Richards, J. C., dan Schmidt, R. (2010). Longman Dictionary of Language Teaching and Applied Linguistics. London: Longman Pearson Education.

Sayuti, Sumitro A. (2014). Prosiding Seminar Nasional Bahasa dan Sastra dalam Perspektif Ekologi dan Multikulturalisme. Yogyakarta: Fakultas Bahasa dan Seni UNY.

White, Randy. (2006). Young Children's Relationship with Nature: Its Importance to Children's Development and the Earth's Future. The Coalition for Education in the Outdoor. 